\title{
In situ studies of metabolism in benthic reef communities
}

\author{
J. M. Wells, A. H. Wells \& J. G. VanDerwalker \\ Manned Undersea Science and Technology Program, \\ National Oceanic and Atmospheric Administration; \\ Rockville, Maryland, USA
}

\begin{abstract}
KURZFASSUNG: In-situ-Studien über den Stoffwechsel benthonischer Lebensgemeinschaften des Korallenriffs. Im Rahmen mehrerer amerikanischer Unterwasser-Forschungsprogramme wurden Stoffwechseluntersuchungen in verschiedenen Korallenriffen an Benthostieren durchgeführt, die in symbiotischer Partnerschaft mit Zooxanthellen leben. An Korallen- und Tridacna-Arten wurden in situ die Beziehungen zwischen Nettophotosynthese und Sauerstoffverbrauch (P/R-Verhältnis) gemessen. Als Maximalwert wurde bei Manicina areolata ein P/R-Verhältnis von 2,9 ermittelt. Die auf einen Zeitraum von 24 Stunden bezogenen Durchschnittswerte lagen $z$ wischen 0,79 und 0,89 . Es wurde festgestellt, daß die photosynthetische Aktivität der Korallen in verunreinigten Riffgebieten stark absinkt.
\end{abstract}

\section{INTRODUCTION}

Benthic marine communities are composed of plants and animals in a great variety of species composition and biomass ratios. These ratios, and the relative metabolic rates of the components of the community, determine whether or not there is a net import or export of food materials, or growth.

One of the most interesting of the many energy pathways within benthic systems is that of the symbiotic invertebrate-algal associations (e.g. coral-zooxanthellae, anemone-zooxanthellae) where an efficient recycling of carbon and inorganic compounds occurs. While the existence of this physiological symbiosis has been known for some time (e.g. Yonge 1936, 1944, WiENs 1962, Nicol 1967), there has been much speculation, but very little quantitative data on the exact nature and magnitude of the nutritional interdependence within the invertebrate-algal associations (cf. TAYLOR 1973).

For the past few years, we have been measuring photosynthesis and respiration of a variety of invertebrate-algal associations and of natural and polluted benthic communities, using both saturation and conventional diving techniques and some rather sophisticated underwater respirometers. We will describe here some of the experiments and results obtained during the Tektite II (Virgin Islands), Florida Aquanaut Research Expedition (FLARE, Florida Keys), R/V Alpha Helix "Billabong” Expedition (Great Barrier Reef, Australia) and R/V Alpha Helix "Symbios" Expedition. 


\section{RESULTS AND DISCUSSION}

Approximately 4 percent of the mantle tissue of tridacdnid clam is composed of zooxanthellae (HAxo et al. 1966), suggesting a rather high potential for photosynthesis in this association. Measurements of oxygen production or consumption of intact clams as a function of light intensity for 4 species shows in fact that 2-4 times the rate of oxygen consumption in darkness is produced during illumination to full sunlight. A $50 \mathrm{~kg}$ Tridacna gigas produced $200 \mathrm{ml} \mathrm{O} / \mathrm{h}$ in full sunlight, 2.1 times as much as consumed in darkness. Rates of photosynthesis and respiration of $T$. squamosa were measured in situ as a function of light intensity and time of day at Eniwetok. By integrating the areas above and below the compensation line on a plot of $\mathrm{O}_{2}$ consumption or production as a function of time of day over a 24 hour period, one obtains the total quantity of $\mathrm{O}_{2}$ produced and consumed during a daily cycle. The ratio of these two quantities ( $\mathrm{P} / \mathrm{R}$ ratio) is the photosynthetic potential of the association, or the maximum possible contribution of algal photosynthesis to the metabolic budget of the association. A P/R ratio of 1.75 was obtained for $T$. squamosa. This means that the clam, with its contained algae, has the potential of obtaining all of its required energy from the photosynthetic activity of the algae alone. Compensation times of day were approximately 7.45 and 18.30 local time. At least 90 percent of photosynthesis was stopped and normal respiration was unaffected by the addition of DCMU, a potent photosynthesis inhibitor, to the water in the respirometer containing Hippopus bippopus.

Table 1

Integrated daily values of the ratio of total photosynthesis to respiration

\begin{tabular}{|cc|}
\hline \multicolumn{1}{c}{ Species } & P/R ratio \\
\hline Acropora cervicornis & .87 \\
Montastrea cavernosa & .89 \\
Manicina areolata var. danaei & .79 \\
\hline
\end{tabular}

Table 2

Maximum photosynthesis to respiration ratios

\begin{tabular}{|lc|}
\hline \multicolumn{1}{c}{ Species } & $\mathrm{P} / \mathrm{R}$ ratio \\
\hline Manicina areolata var. danaei & 2.84 \\
Mussa arrgulosa & 1.15 \\
Montastrea cavernosa & 2.90 \\
Acropora cervicornis & 2.76 \\
Manicina areolata var. areolata & 2.91 \\
Colpophyllia natans & 1.87 \\
Siderastrea siderea & 2.15 \\
\hline
\end{tabular}

During Tektite II, similar experiments were performed on several species of corals at a depth of 60 feet. Rates of $\mathrm{O}_{2}$ production and consumption were determined by 
measuring the change in oxygen pressure with time under Plexaglas domes sealed over the corals. Tables 1 and 2 show the integrated daily $P / R$ ratios and the maximum $P / R$ rate ratios.

Photographs and direct observation showed that the extension and activity of coral polyps is related to light. The "nighttime position" (tentacles extended and active) is assumed shortly after sunset, and the polyps retract promptly at the first light of dawn. The polyps likewise assume their nighttime position during periods of artificially imposed darkness. This made it impossible by the present methods to determine whether the true respiratory rate of the system was the same during periods of illumination as in darkness.

The submersible respirometer used in the previous studies was used to determine the rates of photosynthesis and respiration of a burrowing sea anemone (species to be determined) at Eniwetok. The integrated $P / R$ ration was approximately 0.5 , however, meaning that the maximum contribution the algae could make to the metabolic budget of the association was half of the required energy. Compensation of time of day was 08.00 and 18.15 , respectively.

Photosynthesis on some shallow tropical reef bottoms is so high that, at times, gas bubbles are formed and released into the water. In the past some investigations have used the volume of gas evolved (assumed to be oxygen) to calculate benthic productivity. In situ respirometers show a rather constant oxygen content of approximately 125 percent saturation in shallow water ( 2 meters) while such bubbling is occurring. The $\mathrm{O}_{2}$ content of the evolved gas is only 28-32 percent however. Any calculation of benthic productivity made assuming that the evolved gas is pure $\mathrm{O}_{2}$ will give a value 3-4 times too large. The $\mathrm{O}_{2}$ evolution of (hard) algae-covered pavement at Eniwetok Atoll reached a maximum of $5.5 \times 10^{-3} \mathrm{ml} / \mathrm{cm}^{2} / \mathrm{h}$ on a bright day. The maximum photosynthesis to respiration rate ratio for such areas was 1.6 . Coral rubble produced about half as much.

The productivity of mixed benthic communities and individual coral heads may be reduced considerably or even stopped by pollution. Suspended material in the water column can reduce the light levels to the point where significant photosynthesis does not occur, or, the dissolved components of river and bay effluents may destroy photosynthetic capacity. During the FLARE expedition comparative study was made of benthic metabolism in a clean "control" reef area off southeast Florida and in an area affected by the effluent of Biscayne Bay. The latter area contained noticeably fewer living corals, and many with a "bleached out" appearance, apparently due to the low abundance or lack of symbiotic algae. Such corals have very low photosynthetic capacity and those completely lacking zooxanthellae consumed $\mathrm{O}_{2}$ at a rate comparable to that of normal corals in the dark.

It is interesting that corals completely lacking symbiotic algae assumed the "nightime position" described earlier during daylight hours. When an enclosed portion of a Montastrea cavernosa head is exposed to twice the ambient oxygen during darkness, the enclosed polyps are only partially extended while those outside are fully extended. This suggests that some component of photosynthetic or respiratory processes, probably oxygen, acts as a stimulus for this response. 


\section{SUMMARY}

1. Rates of net photosynthesis and respiration were determined in situ for Tridacna and coral species and their contained zooxanthellae at depths from 9 to $18 \mathrm{~m}$.

2. Integrated daily total net photosynthesis to respiration ratios (P/R ratio) were calculated from these data to obtain the potential contribution of algal photosynthesis to the energy budget of the coral-algal symbiotic association.

3. The integrated daily $P / R$ ratios varied between 0.79 and .89 . Maximum ratios of photosynthesis to respiration rates ranged from 1.15 for Mussa arrgulosa to 2.91 for Manicina areolata.

4. Similar measurements were made on mixed benthic communities off southeastern Florida (USA) in a clean, unpolluted area and in an area influenced by the effluent of Biscayne Bay (USA). Very significant differences were found.

\section{LITERATURE CITED}

Haxo, F. T., Wells, J. M. \& Grant, B., 1966. R/V Alpha Helix Billabong Expedition Reports. University of California, La Jolla, Calif.

Nicol, J. A. C., 1967. The biology of marine animals. Pitman, London, 699 pp.

TAYLoR, D. L., 1973. Symbiotic pathways of carbon in coral reef ecosystems. Present status and future prospects. Helgoländer wiss. Meeresunters. 24, 276-283.

WIENS, H. J., 1962. Atoll environment and ecology. Yale Univ. Press, New Haven, Conn., $532 \mathrm{pp}$.

YONGE, C. M., 1936. Mode of life, feeding, digestion and symbiosis with zooxanthellae in the Tridacnidae. Scient. Rep. Gt Barrier Reef Exped. 1, 283-321.

- 1944. Experimental analysis of the association between invertebrates and unicellular algae. Biol. Rev. 19, 68-80.

First author's address: Dr. J. M. WeLLs

Manned Undersea Science \& Technology Program

National Oceanic and Atmospheric Administration

Rockville, Md. 20852

USA 